\section{Methyl Bromide Alternatives for High Tunnel Strawberry Production in Southern Spain}

\author{
José M. López-Aranda ${ }^{1}$, Luis Miranda ${ }^{1}$, Juan J. Medina ${ }^{1}$, \\ Carmen Soria ${ }^{1}$, Berta de los Santos ${ }^{1}$, Fernando Romero ${ }^{1}$, \\ Rosa M. Pérez-Jiménez ${ }^{1}$, Miguel Talavera ${ }^{1}$, \\ Steve A. Fennimore ${ }^{2}$, and Bielinski M. Santos ${ }^{3,4}$
}

ADDITIONAL INDEX WORDs. soil fumigants, soilborne disease, nematodes, 1,3-dichloropropene, chloropicrin, dazomet, dimethyl disulfide, propylene oxide, calcium cyanamide

Summary. Field trials were conducted in two locations in Spain to determine the effect of methyl bromide (MBr) alternatives on soilborne diseases and nematodes, and strawberry (Fragaria $\times$ ananassa) yields under high-tunnel conditions.

Fumigant treatments were applied to the same plots each year. Treatments were $\mathrm{MBr}+$ chloropicrin $(\mathrm{Pic})(50: 50, \mathrm{v} / \mathrm{v})$ at a rate of $400 \mathrm{~kg} \cdot \mathrm{ha}^{-1} ; 1,3$-dichloropropene $(1,3-\mathrm{D})+\operatorname{Pic}(65: 35, \mathrm{v} / \mathrm{v})$ at $300 \mathrm{~kg} \cdot \mathrm{ha}^{-1} ;$ Pic at $300 \mathrm{~kg} \cdot \mathrm{ha}^{-1}$; dimethyl disulfide $(\mathrm{DMDS})+\operatorname{Pic}(50: 50, \mathrm{v} / \mathrm{v})$ at $500 \mathrm{~kg} \cdot \mathrm{ha}^{-1}$; propylene oxide at $550 \mathrm{~kg} \cdot \mathrm{ha}^{-1}$; dazomet at $400 \mathrm{~kg} \cdot \mathrm{ha}^{-1}$; and calcium cyanamide (Ca-cyanamide) at $700 \mathrm{~kg} \cdot \mathrm{ha}^{-1}$. A nontreated control was also included. Fumigation with $\mathrm{MBr}+\mathrm{Pic}, 1,3-\mathrm{D}+\mathrm{Pic}$, Pic, and DMDS + Pic consistently improved early and total marketable strawberry yields in both locations. This response was caused by successful soilborne fungus and nematode control, improving strawberry growth and development, which resulted in increased plant canopy diameters and higher strawberry early and total yield.

S trawberry production in Spain has exclusively relied upon the use of methyl bromide ( $\mathrm{MBr}$ ) alone or in combination with chloropicrin (Pic) as preplant soil fumigation treatments for control of soilborne diseases, nematodes, and weeds (Calatrava, 2002; Duniway, 2002). As a result of the Montreal Protocol on substances that deplete atmospheric ozone, $\mathrm{MBr}$ has been phased out for agricultural purposes in the majority of developed countries (Albritton et al., 1998; U.S. Environmental Protection Agency, 1999). Nonchemical treatments for soil disinfestation for strawberry production such as steam, soil solarization, soilless cultivation, biofumigation, and others are still considered risky and/or not economically feasible to be used alone as global alternatives to $\mathrm{MBr}$ (Ajwa et al., 2003). Therefore, open-field production of strawberry with standard soil fumigation will continue

${ }^{1}$ Instituto Andaluz de Investigación y Formación Agraria, Consejería de Innovación, Ciencia y Empresa, Junta de Andalucía, Málaga, Spain

${ }^{2}$ Department of Plant Sciences, University of California at Davis, Salinas, CA 93905

${ }^{3}$ Gulf Coast Research and Education Center, IFAS, University of Florida, Wilmauma, FL 33598

${ }^{4}$ Corresponding author. E-mail: bmsantos@ufl.edu. being the predominant production system in the near future.

Research on $\mathrm{MBr}$ alternatives has been intensive throughout the world in the last 15 years (Ajwa et al., 2003; Duniway, 2002; Rosskopf et al., 2005; Santos and Gilreath, 2006). Some of the proposed alternatives for mulched-vegetable crops are the combination of 1,3-dichloropropene $(1,3-\mathrm{D})$ and Pic, dazomet, propylene oxide, dimethyl disulfide (DMDS) plus Pic, and calcium cyanamide (C-cyanamide). The combination of $1,3-\mathrm{D}+$ Pic has been widely studied throughout the world for controlling fungal disease and nematodes. However, herbicides frequently need to be included along with this alternative to enhance activity against weeds (Noling and Gilreath, 2001).
Dazomet is a generator of the biocide methyl isothiocyanate and has shown acceptable control of soilborne diseases and nematodes in vegetable crops, but its activity can be inconsistent (Rosskopf et al., 2005; Santos and Gilreath, 2006). In turf and strawberry, propylene oxide has provided broad-spectrum control against soilborne diseases, nematodes, and weeds in preliminary tests (Belcher et al., 2004; Norton, 2004). In tomato (Solanum lycopersicum), studies indicated that populations of sting nematode (Belonolaimus spp.) and nutsedge (Cyperus spp.) rapidly decreased with $570 \mathrm{~kg} \cdot \mathrm{ha}^{-1}$ of shank-applied propylene oxide, and the highest fruit weights were obtained with application of 760 and $950 \mathrm{~kg} \cdot \mathrm{ha}^{-1}$ (Santos and Gilreath, 2005). However, strawberry plots treated with this product failed to reach the same yield as in the $\mathrm{MBr}+$ Pic plots (Santos et al., 2006). DMDS has fungicidal and nematicidal properties and can be shankinjected and combined with other fumigants. A study demonstrated that application of DMDS reduced populations of Pythium ultimum and Fusarium oxysporum (Gerik, 2005). However, other research has shown inconsistent results in controlling soilborne diseases (De Cal et al., 2004). A strawberry study showed that application of DMDS + Pic $(50: 50, \mathrm{v} / \mathrm{v})$ at a rate of $250+250$ $\mathrm{kg} \cdot \mathrm{ha}^{-1}$ resulted in higher early and total strawberry yields than the nontreated control, whereas there was no yield difference in comparison with $\mathrm{MBr}+$ Pic (Santos et al., 2006). A drawback of this fumigant is its intense odor, which persists in the soil for several weeks after application. Ca-cyanamide is mainly used a fertilizer, but it has fungicidal and nematicidal activity in soils planted with sunflower (Helianthus annuus) and pea (Pisum satioum) (Jones and Gray,

\begin{tabular}{llll}
\hline $\begin{array}{l}\text { Units } \\
\begin{array}{l}\text { To convert U.S. to SI, } \\
\text { multiply by }\end{array}\end{array}$ & U.S. unit & SI unit & $\begin{array}{l}\text { To convert SI to U.S., } \\
\text { multiply by }\end{array}$ \\
\hline 29.5735 & $\mathrm{fl} \mathrm{oz}$ & $\mathrm{mL}$ & 0.0338 \\
0.3048 & $\mathrm{ft}$ & $\mathrm{m}$ & 3.2808 \\
0.0929 & $\mathrm{ft}^{2}$ & $\mathrm{~m}^{2}$ & 10.7639 \\
0.1242 & gal/100 ft & $\mathrm{L} \cdot \mathrm{m}^{-1}$ & 8.0520 \\
2.54 & inch $(\mathrm{es})$ & $\mathrm{cm}$ & 0.3937 \\
1.1209 & lb/acre & $\mathrm{kg} \cdot \mathrm{ha}^{-1}$ & 0.8922 \\
0.0254 & $\mathrm{mil}$ & $\mathrm{mm}$ & 39.3701 \\
28.3495 & $\mathrm{oz}$ & $\mathrm{g}$ & 0.0353 \\
$\left({ }^{\circ} \mathrm{F}-32\right) \div 1.8$ & $\mathrm{o} F$ & ${ }^{\circ} \mathrm{C}$ & $\left(1.8 \times{ }^{\circ} \mathrm{C}\right)+32$
\end{tabular}


1973; Lo and Lin, 1989; Milinko et al., 1989). Its fungicidal activity is based on the release of cyanamide, bicyanamide, and guanidine (Bourdos et al., 1997).

Southern Spain is the most important strawberry-producing area of Europe (Food and Agriculture Organization of the United Nations, 2008). The most common application techniques in this area use shankinjection of $\approx 400 \mathrm{~kg} \cdot \mathrm{ha}^{-1}$ of $\mathrm{MBr}+$ Pic in preformed beds. Fungal diseases and nematodes are major causes of economic losses in strawberry throughout the world. The main soilborne diseases in southern Spain are crown rot (Phytophthora cactorum), verticillium wilt (Verticillium spp.), and black root rot (Fusarium spp., Rhizoctonia spp., Pythium spp., and Cylindrocarpon spp.) (De Los Santos et al., 2003). Root-knot nematode (Meloidogyne spp.) and lesion nematode (Pratylenchus spp.) are also serious limiting factors for strawberry production, causing severe root galling and lesions, respectively. Thus far, these pathogens have been effectively controlled with $\mathrm{MBr}$. There are few research reports on the effect of $\mathrm{MBr}$ alternatives under high-tunnel conditions. Therefore, the objective of this study was to determine their efficacy on soilborne diseases and nematodes for high tunnel strawberry production in southern Spain.

\section{Materials and methods}

Four field trials were conducted in two grower fields located at Moguer (lat. $37^{\circ} 17^{\prime} \mathrm{N}$, long. $6^{\circ} 51^{\prime} \mathrm{W}$ ) and Palos de la Frontera (lat. $37^{\circ} 14^{\prime} \mathrm{N}$, long. $\left.6^{\circ} 53^{\prime} \mathrm{W}\right)$, Spain, during the 2003-04 and 2004-05 seasons. These experimental sites are major high tunnel strawberry production areas in Spain, and their soils are loamy sands with organic matter content between $0.4 \%$ and $0.6 \%$, and a $\mathrm{pH}$ between 6.7 and 7.1. Beds were formed with a tractor-mounted bed presser, and their dimensions were 30 and $60 \mathrm{~cm}$ wide and high, respectively. Simultaneously with bed pressing, a single drip line with a flow rate of $1.56 \mathrm{~L} \cdot \mathrm{m}^{-1}$ per hour and emitters every $30 \mathrm{~cm}$ was placed $5 \mathrm{~cm}$ deep on bed centers, beds were covered with polyethylene mulch, and volatile fumigants were injected $20 \mathrm{~cm}$ deep with four chisels per bed. At Palos de la Frontera, fumigants were applied on 9 Sept.
2003 and 7 Sept. 2004, whereas at Moguer these operations were performed on 16 Sept. 2003 and 14 Sept. 2004. Average soil temperatures during fumigation were between 25 and $29^{\circ} \mathrm{C}$ at both locations.

Eight fumigant treatments with four replications were established in randomized complete blocks at each location. Experimental units were three 24 -m-long beds $\left(43.2 \mathrm{~m}^{2}\right.$ per plot). Fumigants used in this study were commercial-grade formulations, with the exception of DMDS + Pic and propylene oxide, which had experimental labels. Fumigant treatments were applied to the same plots each year. $\mathrm{MBr}+\operatorname{Pic}(50: 50, \mathrm{v} / \mathrm{v})$ was applied at a rate of $400 \mathrm{~kg} \cdot \mathrm{ha}^{-1} ; \mathrm{l}, 3-\mathrm{D}$ $+\operatorname{Pic}(65: 35, \mathrm{v} / \mathrm{v})$ at $300 \mathrm{~kg} \cdot \mathrm{ha}^{-1} ; \mathrm{Pic}$ at $300 \mathrm{~kg} \cdot \mathrm{ha}^{-1}$; DMDS + Pic (50:50, $\mathrm{v} / \mathrm{v}$ ) at $500 \mathrm{~kg} \cdot \mathrm{ha}^{-1}$; propylene oxide at $550 \mathrm{~kg} \cdot \mathrm{ha}^{-1}$; dazomet at $400 \mathrm{~kg} \cdot \mathrm{ha}^{-1}$; and $\mathrm{Ca}$-cyanamide at $700 \mathrm{~kg} \cdot \mathrm{ha}^{-1}$. These rates were based on the total mulched area. A nontreated control was also included. Propylene oxide and Ca-cyanamide were broadcast by hand on bed tops and were incorporated $5 \mathrm{~cm}$ deep within $2 \mathrm{~h}$ after application with a conventional cultivator. The nontreated and the $\mathrm{MBr}+$ Pic-injected plots were mulched with black polyethylene (1 mil), which reflects the standard grower practice. All other treatments were mulched with black, virtually impermeable film ( $1.5 \mathrm{mil})$, which increases retention of volatile fumigants and exposure of soil pests to lethal fumes.

High tunnels were built using semicircular steel bars that reached $3.3 \mathrm{~m}$ high on the tunnel apex and were $8.3 \mathrm{~m}$ wide. These bars were mounted on $1.8 \mathrm{~m}$-long side support bars. Each high-tunnel had six beds and was covered with translucent polyethylene plastic, which allowed in $60 \%$ of the photosynthetic active radiation. Tunnels were covered on 22 Nov. 2003 and 8 Nov. 2004 at Moguer, and on 14 Nov. 2003 and 11 Nov. 2004 at Palos de la Frontera. Bare-root 'Camarosa' strawberry plants from commercial California nurseries were transplanted on 14 Oct. 2003 and 11 Oct. 2004 at Palos de la Frontera, and on 22 Oct. 2003 and 11 Oct. 2004 at Moguer. Transplants were placed in double rows per mulched bed and were spaced $27 \times$ $22 \mathrm{~cm}$, and $26 \times 25 \mathrm{~cm}$ apart between rows and plants at Moguer and Palos de la Frontera, respectively. Transplant establishment used intermittent application of drip and microsprinkler irrigation during the first $10 \mathrm{~d}$ to ensure the cooling down of strawberry crowns. Conventional crop management was followed as recommended in the region for strawberry production under plastic tunnels (López-Aranda et al., 2002).

Fumigant efficacy on soilborne fungal populations was estimated for the genera Rhizoctonia, Phytophthora, Fusarium, Trichoderma, and Pythium by comparison of their number of colony-forming units (cfu) per gram of soil. Five soil samples per plot were obtained before fumigant application and $30 \mathrm{~d}$ after fumigation during each season and location to determine number of cfu. Samples were taken $20 \mathrm{~cm}$ deep between two plants in the same row by using a vertical soil core sampler (2-cm diameter). Afterward, soil samples were dried and $1 \mathrm{~g}$ of soil per sample was suspended in $99 \mathrm{~mL}$ of water agar $(0.3 \%, \mathrm{v} / \mathrm{v})$. Aliquots of $1 \mathrm{~mL}$ were spread on petri dishes with $\mathrm{P}_{5} \mathrm{ARP}$ semiselective agar medium to determine the presence of Phytophthora and Pythium (Jeffers and Martin, 1986); and $\mathrm{KO}$ agar medium to determine the presence of Rhizoctonia (Ko and Hora, 1971). Trichoderma isolations with $10 \mathrm{~g}$ of soil were suspended in $90 \mathrm{~mL}$ of water $\operatorname{agar}(0.3 \%, \mathrm{v} / \mathrm{v})$, shaken for $15 \mathrm{~min}$, and $0.1-\mathrm{mL}$ aliquots were spread with a glass rod on petri dishes with Trichoderma-selective medium (Elad et al., 1981). Petri dishes were placed at $25^{\circ} \mathrm{C}$ in the dark for 3 to $7 \mathrm{~d}$ and the fungal colonies were counted. Nematode populations were determined at the end of each season by selecting five plants per plot $(240$ plants per location). Strawberry root samples from each plant were washed with distilled water and sedentary forms of root-knot nematode at the juvenile 3 and 4 , and adult stages, and endoparasitic forms of lesion nematode at the juvenile 2,3 , and 4 , and adult stages were extracted and quantified by the sugar centrifugation method (Nombela and Bello, 1983).

Strawberry plant diameter was recorded at 10 weeks after transplanting to assess plant growth and it was determined by averaging two horizontal measurements (north-south and east-west) of aboveground 
foliage of 10 previously selected plants per plot. Marketable fruit were collected at least twice per week at each experimental site. The first strawberry harvest occurred on 30 Jan. 2004 and 21 Jan. 2005 at Moguer, and on 20 Jan. 2004 and 11 Jan. 2005 at Palos de la Frontera. At each location, a minimum of 25 harvests was conducted, which is representative of current grower practices. Early marketable yields comprised all harvests until 31 March of each season, whereas total marketable yields were the cumulative fruit weights of all harvests. Early and total weights per fruit were calculated by dividing early and total marketable yields by their respective fruit numbers. Data were analyzed with analysis of variance and treatment means were compared using Fisher's protected least significant difference test at the $5 \%$ significance level (Statistix, version 8.0; Analytical Software, Tallahassee, FL). Before analysis, nematode populations were transformed with $\log$ $(\mathrm{x}+\mathrm{l})$ to normalize the data.

\section{Results and discussion}

There were significant season by treatment interactions at Moguer and Palos de la Frontera. Therefore, data from each season for each location were analyzed separately. At Moguer, there was significant fumigant effect on the number of recovered cfu of Rhizoctonia, Phytophthora, Fusarium, Trichoderma, and Pythium recovered from sampled soil during the 200304 and 2004-05 seasons (Table 1). There were no significant differences on the number of fungal cfu obtained from the plots before fumigation (data not shown), indicating uniform distribution of fungal populations within each experimental site and season. However, fumigant treatments affected the number of fungal cfu obtained at $30 \mathrm{~d}$ after application during all four trials. During the first season at Moguer, the nontreated control plots showed the largest number of fungal cfu among all treatments $(47,300 \mathrm{cfu} / \mathrm{g}$ of soil $)$, whereas all fumigated plots ranged between 0 and $22,000 \mathrm{cfu} / \mathrm{g}$ of soil. The following season at the same location, fungal cfu values ranged between 0 and $56,100 \mathrm{cfu} / \mathrm{g}$ of soil, and the lowest values occurred in plots treated with $\mathrm{MBr}+\mathrm{Pic}, 1,3-\mathrm{D}+\mathrm{Pic}, \mathrm{Pic}, \mathrm{DMDS}+$ Pic, and dazomet $(\leq 9,900 \mathrm{cfu} / \mathrm{g}$ of soil), which were not different from each other. Soil treatment with $\mathrm{Ca}-$ cyanamide or propylene oxide did not reduce the number of fungal cfu in comparison with the nontreated control $(56,100 \mathrm{cfu} / \mathrm{g}$ of soil $)$. At Palos de la Frontera, the fumigants had significant effects on the number of cfu during both growing seasons. In 2003-04, plots fumigated with $\mathrm{Ca}^{-}$ cyanamide had the same fungal cfu values as those obtained in the nontreated control, while during the following season, this product and propylene oxide failed to reduce the number of cfu in relation to nontreated control plots (Table 2). At both locations, plots treated with dazomet, 1,3-D + Pic, Pic, and DMDS + Pic consistently had the same number of cfu than those treated with $\mathrm{MBr}+\mathrm{Pic}$ in both seasons.

At Moguer, fumigant treatments affected the populations of juveniles of lesion nematode on strawberry roots during the 2003-04 season, but not in 2004-05 (Table 1). During the first season, control of lesion nematode was the highest in plots treated with $\mathrm{MBr}+\mathrm{Pic}, 1,3-\mathrm{D}+\mathrm{Pic}$,

Table 1. Effects of fumigation treatments on the number of fungal colony-forming units ( $\mathrm{cfu}$ ) and lesion nematode populations on strawberry roots during the 2003-04 and 2004-05 strawberry seasons at Moguer, Spain.

\begin{tabular}{|c|c|c|c|c|}
\hline \multirow[b]{3}{*}{ Fumigants ${ }^{\mathrm{z}}$} & \multicolumn{2}{|c|}{ Fungal cfu } & \multicolumn{2}{|c|}{$\begin{array}{l}\text { Lesion nematode } \\
\text { population }\end{array}$} \\
\hline & $2003-04$ & $2004-05$ & $2003-04$ & 2004-05 \\
\hline & \multicolumn{2}{|c|}{$(100 / \mathrm{g} \text { of soil })^{y}$} & \multicolumn{2}{|c|}{ (no./g of root) } \\
\hline Control & $47.3 \mathrm{a}^{\mathrm{x}}$ & $56.1 \mathrm{a}$ & $50.1 \mathrm{ab}$ & $181.0 \mathrm{a}$ \\
\hline $\mathrm{MBr}+\mathrm{Pic}$ & $7.7 \mathrm{bc}$ & $0 \mathrm{c}$ & $6.3 c$ & $251.0 \mathrm{a}$ \\
\hline Dazomet & $0 \mathrm{c}$ & $9.9 \mathrm{bc}$ & $112.0 \mathrm{ab}$ & $135.0 \mathrm{a}$ \\
\hline $1,3-\mathrm{D}+\mathrm{Pic}$ & $22.0 \mathrm{~b}$ & $1.1 \mathrm{c}$ & $9.8 \mathrm{c}$ & $76.0 \mathrm{a}$ \\
\hline Pic & $0 \mathrm{c}$ & $3.3 \mathrm{c}$ & $83.8 \mathrm{ab}$ & $215.0 \mathrm{a}$ \\
\hline $\mathrm{DMDS}+\mathrm{Pic}$ & $1.1 \mathrm{bc}$ & $3.3 \mathrm{c}$ & $12.7 \mathrm{c}$ & $18.0 \mathrm{a}$ \\
\hline Ca-cyanamide & $4.4 \mathrm{bc}$ & $44.0 \mathrm{ab}$ & $51.5 \mathrm{ab}$ & $69.0 \mathrm{a}$ \\
\hline Propylene oxide & $0 \mathrm{c}$ & $70.4 \mathrm{a}$ & $242.0 \mathrm{a}$ & $165.0 \mathrm{a}$ \\
\hline Significance $(P<0.05)$ & * & * & * & NS \\
\hline \multicolumn{5}{|c|}{ 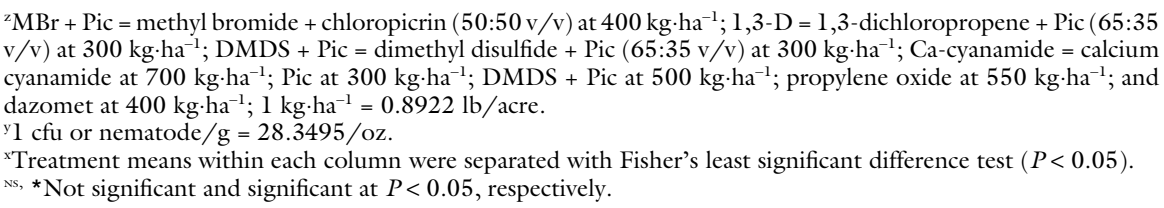 } \\
\hline
\end{tabular}

Table 2. Effects of fumigation treatments on the number of fungal colony-forming units (cfu), and root-knot nematode populations on strawberry roots during the 2003-04 and 2004-05 strawberry seasons at Palos de la Frontera, Spain.

\begin{tabular}{|c|c|c|c|c|}
\hline \multirow[b]{3}{*}{ Fumigants ${ }^{\mathrm{z}}$} & \multicolumn{2}{|c|}{ Fungal cfu } & \multicolumn{2}{|c|}{$\begin{array}{l}\text { Root-knot nematode } \\
\text { population }\end{array}$} \\
\hline & 2003-04 & 2004-05 & $2003-04$ & 2004-05 \\
\hline & \multicolumn{2}{|c|}{$(1000 / \mathrm{g} \text { of soil })^{\mathrm{y}}$} & \multicolumn{2}{|c|}{ (no./g of root) } \\
\hline Control & $72.6 \mathrm{a}^{\mathrm{x}}$ & $36.3 \mathrm{a}$ & $20.9 \mathrm{ab}$ & $22.5 \mathrm{a}$ \\
\hline $\mathrm{MBr}+\mathrm{Pic}$ & $19.8 \mathrm{~b}$ & $1.1 \mathrm{c}$ & $1.8 \mathrm{c}$ & $2.3 \mathrm{a}$ \\
\hline Dazomet & $3.3 \mathrm{~b}$ & $13.2 \mathrm{bc}$ & $27.9 \mathrm{ab}$ & $10.1 \mathrm{a}$ \\
\hline $1,3-\mathrm{D}+\mathrm{Pic}$ & $14.3 \mathrm{~b}$ & $7.7 \mathrm{bc}$ & $0 \mathrm{c}$ & $0.9 \mathrm{a}$ \\
\hline Pic & $4.4 \mathrm{~b}$ & $5.5 \mathrm{bc}$ & $0 \mathrm{c}$ & $3.5 \mathrm{a}$ \\
\hline $\mathrm{DMDS}+\mathrm{Pic}$ & $1.1 \mathrm{~b}$ & $13.2 \mathrm{bc}$ & $0 \mathrm{c}$ & $0.3 \mathrm{a}$ \\
\hline Ca-cyanamide & $36.3 \mathrm{ab}$ & $22.0 \mathrm{ab}$ & $32.4 \mathrm{a}$ & $20.7 \mathrm{a}$ \\
\hline Propylene oxide & $19.8 \mathrm{~b}$ & $34.1 \mathrm{a}$ & $17.0 \mathrm{~b}$ & $16.5 \mathrm{a}$ \\
\hline Significance $(P<0.05)$ & * & * & * & NS \\
\hline
\end{tabular}

${ }^{\mathrm{z}} \mathrm{MBr}+\mathrm{Pic}=$ methyl bromide + chloropicrin $(50: 50 \mathrm{v} / \mathrm{v})$ at $400 \mathrm{~kg} \cdot \mathrm{ha}^{-1} ; \mathrm{l}, 3-\mathrm{D}=1,3$-dichloropropene + Pic $(65: 35$ $\mathrm{v} / \mathrm{v})$ at $300 \mathrm{~kg} \cdot \mathrm{ha}^{-1} ; \mathrm{DMDS}+\mathrm{Pic}=$ dimethyl disulfide $+\operatorname{Pic}(65: 35 \mathrm{v} / \mathrm{v})$ at $300 \mathrm{~kg} \cdot \mathrm{ha}^{-1} ; \mathrm{Ca}-\mathrm{cyanamide}=\mathrm{calcium}$ cyanamide at $700 \mathrm{~kg} \cdot \mathrm{ha}^{-1}$; Pic at $300 \mathrm{~kg} \cdot \mathrm{ha}^{-1}$; DMDS + Pic at $500 \mathrm{~kg} \cdot \mathrm{ha}^{-1}$; propylene oxide at $550 \mathrm{~kg} \cdot \mathrm{ha}^{-1}$; and dazomet at $400 \mathrm{~kg} \cdot \mathrm{ha}^{-1} ; \mathrm{l} \mathrm{kg} \cdot \mathrm{ha}^{-1}=0.8922 \mathrm{lb} /$ acre.

${ }^{\mathrm{y}} \mathrm{l}$ cfu or nematode $/ \mathrm{g}=28.3495 / \mathrm{oz}$.

${ }^{x}$ Treatment means within each column were separated with Fisher's least significant difference test $(P<0.05)$.

Ns, * Not significant and significant at $P<0.05$, respectively. 
and DMDS + Pic $(<13$ juveniles per gram of root), whereas dazomet, Pic, Ca-cyanamide, and propylene oxide were equal to the nontreated control. At Palos de la Frontera, root-knot nematode juveniles on strawberry roots were influenced by fumigation in 2003-04, but not in 2004-05 (Table 2). Plots treated with $\mathrm{MBr}+$ Pic, 1,3-D + Pic, Pic, and DMDS + Pic showed the highest root-knot nematode control among all treatments ( $<2$ juveniles per gram of root), whereas dazomet and $\mathrm{Ca}$-cyanamide were not different from the nontreated control in the 2003-04 season.

Strawberry plant diameter, early and total marketable yield, and early and total weight per fruit were influenced by the application of the fumigants at both locations. At Moguer, there were no plant diameter differences among plots treated with $\mathrm{MBr}$ + Pic, 1,3-D + Pic, Pic, DMDS + Pic, and propylene oxide in the 2003-04 season, ranging between 36.3 and $38.2 \mathrm{~cm}$ of diameter (Table 3 ). The smallest plants were located in the nontreated control plots and in those fumigated with Ca-cyanamide and dazomet $(\leq 34.8 \mathrm{~cm})$. In 2004-05, the largest plant diameters were obtained in plots treated with $1,3-\mathrm{D}$ + Pic, Pic, and DMDS + Pic $(\geq 41.0$ $\mathrm{cm})$, whereas there were no significant canopy differences among the nontreated control, Ca-cyanamide, and propylene oxide $(\leq 34.3 \mathrm{~cm})$. At Palos de la Frontera, plots treated during 2003-04 with $\mathrm{MBr}+\mathrm{Pic}$,
1,3-D + Pic, Pic, DMDS + Pic, and propylene oxide had the largest strawberry plant diameters $(\geq 37.0 \mathrm{~cm})$. The nontreated control and Ca-cyanamide resulted in plants with the same canopy diameter $(\leq 32.9 \mathrm{~cm})$. In 2004 05 , application of dazomet, Ca-cyanamide, and propylene oxide failed to increase plant diameter in comparison with the nontreated control (Table 3 ).

The highest early marketable yields at Moguer during both seasons were obtained in plots treated with $\mathrm{MBr}+\mathrm{Pic}$, dazomet, 1,3-D + Pic, Pic, DMDS + Pic, and propylene oxide, ranging between 314.1 and $374.7 \mathrm{~g} /$ plant (Table 3). Application of Cacyanamide failed to improve early marketable yields in comparison with the nontreated control during both growing seasons. At Palos de la Frontera, there were no significant early marketable yield differences in 200304 among all fumigated plots, with the exception of Ca-cyanamide and nontreated plots, ranging between 462.5 and $526.4 \mathrm{~g} /$ plant. The following season, early yields in plots treated with $\mathrm{MBr}+\mathrm{Pic}, 1,3-\mathrm{D}+\mathrm{Pic}$, Pic, DMDS + Pic, and propylene oxide were statistically equal. Plots fumigated with dazomet, Ca-cyanamide, and the nontreated control showed no significant early yield differences.

Across locations and seasons, the highest total marketable yields were consistently obtained with the application of $\mathrm{MBr}+\mathrm{Pic}, 1,3-\mathrm{D}+\mathrm{Pic}$, Pic, and DMDS + Pic, with values ranging between 1006.3 and $1268.8 \mathrm{~g} /$ plant and 793.0 and $1315.0 \mathrm{~g} /$ plant at Moguer and Palos de la Frontera, respectively (Tables 3 and 4). During the 2003-04 season at both locations, total marketable yield in plots treated with propylene oxide did not differ from those injected with DMDS + Pic, but this effect disappeared the following season, when this fumigant performed better than the nontreated control but worse than DMDS + Pic. Application of Ca-cyanamide failed to increase total marketable yields with respect to the nontreated control. Dazomet produced comparable total yield to those in $\mathrm{MBr}+$ Pic plots in three of four trials.

At Moguer, values for early weight per fruit in plots fumigated with $\mathrm{MBr}+$ Pic, dazomet, 1,3-D + Pic, Pic, and DMDS + Pic were statistically equal within each season, with values ranging between 27.9 and $32.1 \mathrm{~g} /$ fruit and 30.9 and $33.2 \mathrm{~g} /$ fruit in the 2003 04 and 2004-05 seasons, respectively (Table 3). In 2003-04, early weight per fruit in propylene oxide-treated plots was similar to that obtained with $\mathrm{MBr}+\mathrm{Pic}$, while there were no differences between the nontreated control and Ca-cyanamide. At Palos de la Frontera, fumigation with $\mathrm{MB}+\mathrm{Pic}$, dazomet, 1,3-D + Pic, Pic, and DMDS + Pic consistently improved early weight per fruit $(\geq 30.7 \mathrm{~g} /$ fruit both seasons) in contrast with the nontreated control $(22.5$ and $23.0 \mathrm{~g} /$ fruit in 2003-04 and 2004-05). Total weight per fruit followed a similar trend as early weight per fruit within

Table 3. Effects of fumigation treatments on strawberry plant diameter, early and total marketable fruit, and early and total weight per fruit during the 2003-04 and 2004-05 strawberry seasons at Moguer, Spain.

\begin{tabular}{|c|c|c|c|c|c|c|c|c|c|c|}
\hline \multirow[b]{3}{*}{ Fumigants ${ }^{\mathrm{z}}$} & \multicolumn{2}{|c|}{ Plant diameter } & \multicolumn{2}{|c|}{$\begin{array}{c}\text { Early marketable } \\
\text { yield }\end{array}$} & \multicolumn{2}{|c|}{$\begin{array}{c}\text { Total marketable } \\
\text { yield }\end{array}$} & \multicolumn{2}{|c|}{ Early wt } & \multicolumn{2}{|c|}{ Total wt } \\
\hline & $2003-04$ & 2004-05 & 2003-04 & 2004-05 & $2003-04$ & $\overline{2004-05}$ & $\overline{2003-04}$ & $2004-05$ & 2003-04 & $2004-05$ \\
\hline & \multicolumn{2}{|c|}{$(\mathrm{cm})^{y}$} & \multicolumn{2}{|c|}{$\left(\mathrm{g} /\right.$ plant $^{\mathrm{y}}$} & \multicolumn{2}{|c|}{ (g/plant) } & \multicolumn{2}{|c|}{ (g/fruit) } & \multicolumn{2}{|c|}{ (g/fruit) } \\
\hline Control & $32.1 \mathrm{~d}^{\mathrm{x}}$ & $32.5 \mathrm{~d}$ & $178.0 \mathrm{~b}$ & $237.4 \mathrm{c}$ & $703.3 \mathrm{c}$ & $861.4 \mathrm{~d}$ & $22.5 \mathrm{~b}$ & $23.0 \mathrm{c}$ & $22.6 \mathrm{~b}$ & $21.5 \mathrm{c}$ \\
\hline $\mathrm{MBr}+\mathrm{Pic}$ & $38.2 \mathrm{a}$ & $37.3 \mathrm{bc}$ & $349.0 \mathrm{a}$ & $371.0 \mathrm{a}$ & $1,082.0 \mathrm{a}$ & $1,164.0 \mathrm{ab}$ & $32.1 \mathrm{a}$ & $32.9 \mathrm{a}$ & $28.2 \mathrm{a}$ & $26.9 \mathrm{a}$ \\
\hline Dazomet & $34.8 \mathrm{~cd}$ & $37.7 \mathrm{bc}$ & $317.6 \mathrm{a}$ & $359.9 \mathrm{a}$ & $952.2 \mathrm{~b}$ & $1,152.4 \mathrm{ab}$ & $27.9 \mathrm{a}$ & $30.9 \mathrm{a}$ & $26.2 \mathrm{a}$ & $25.8 \mathrm{a}$ \\
\hline DMDS + Pic & $36.7 \mathrm{abc}$ & $41.0 \mathrm{a}$ & $314.1 \mathrm{a}$ & $374.7 \mathrm{a}$ & $1,006.3 \mathrm{ab}$ & $1,257.1 \mathrm{a}$ & $32.1 \mathrm{a}$ & $31.6 \mathrm{a}$ & $28.2 \mathrm{a}$ & $26.6 \mathrm{a}$ \\
\hline Ca-cyanamide & $32.1 \mathrm{~d}$ & $34.3 \mathrm{~cd}$ & $205.9 \mathrm{~b}$ & $289.4 \mathrm{bc}$ & $714.1 \mathrm{c}$ & $931.2 \mathrm{~cd}$ & $22.1 \mathrm{~b}$ & $27.3 \mathrm{~b}$ & $22.8 \mathrm{~b}$ & $23.9 \mathrm{~b}$ \\
\hline Propylene oxide & $36.7 \mathrm{abc}$ & $36.2 \mathrm{bcd}$ & $331.6 \mathrm{a}$ & $322.8 \mathrm{ab}$ & $1,049.5 \mathrm{ab}$ & $1,047.6 \mathrm{bc}$ & $30.8 \mathrm{a}$ & $26.0 \mathrm{bc}$ & $27.4 \mathrm{a}$ & $22.9 \mathrm{bc}$ \\
\hline Significance & * & * & * & * & * & * & * & * & * & * \\
\hline
\end{tabular}

\section{$(P<0.05)$}

${ }^{\mathrm{z}} \mathrm{MBr}+\mathrm{Pic}=$ methyl bromide + chloropicrin $(50: 50 \mathrm{v} / \mathrm{v})$ at $400 \mathrm{~kg} \cdot \mathrm{ha}^{-1} ; \mathrm{l}, 3-\mathrm{D}=1,3$-dichloropropene + Pic $(65: 35 \mathrm{v} / \mathrm{v})$ at $300 \mathrm{~kg} \cdot \mathrm{ha}{ }^{-1} ; \mathrm{DMDS}+\mathrm{Pic}=$ dimethyl disulfide + Pic

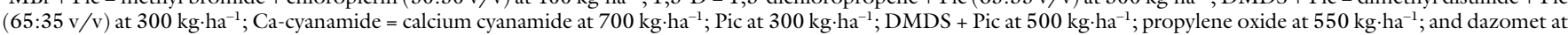
$400 \mathrm{~kg} \cdot \mathrm{ha}^{-1} ; \mathrm{l} \mathrm{kg} \cdot \mathrm{ha}^{-1}=0.8922 \mathrm{lb} / \mathrm{acre}$.

${ }^{\mathrm{y}} 1 \mathrm{~cm}=0.3937$ inch; $1 \mathrm{~g}=0.0353 \mathrm{oz}$.

xTreatment means within each column were separated with Fisher's least significant difference test $(P<0.05)$.

* Significant at $P<0.05$. 
Table 4. Effects of fumigation treatments on strawberry plant diameter, early and total marketable fruit, and early and total weight per fruit during the 2003-04 and 2004-05 strawberry seasons at Palos de la Frontera, Spain.

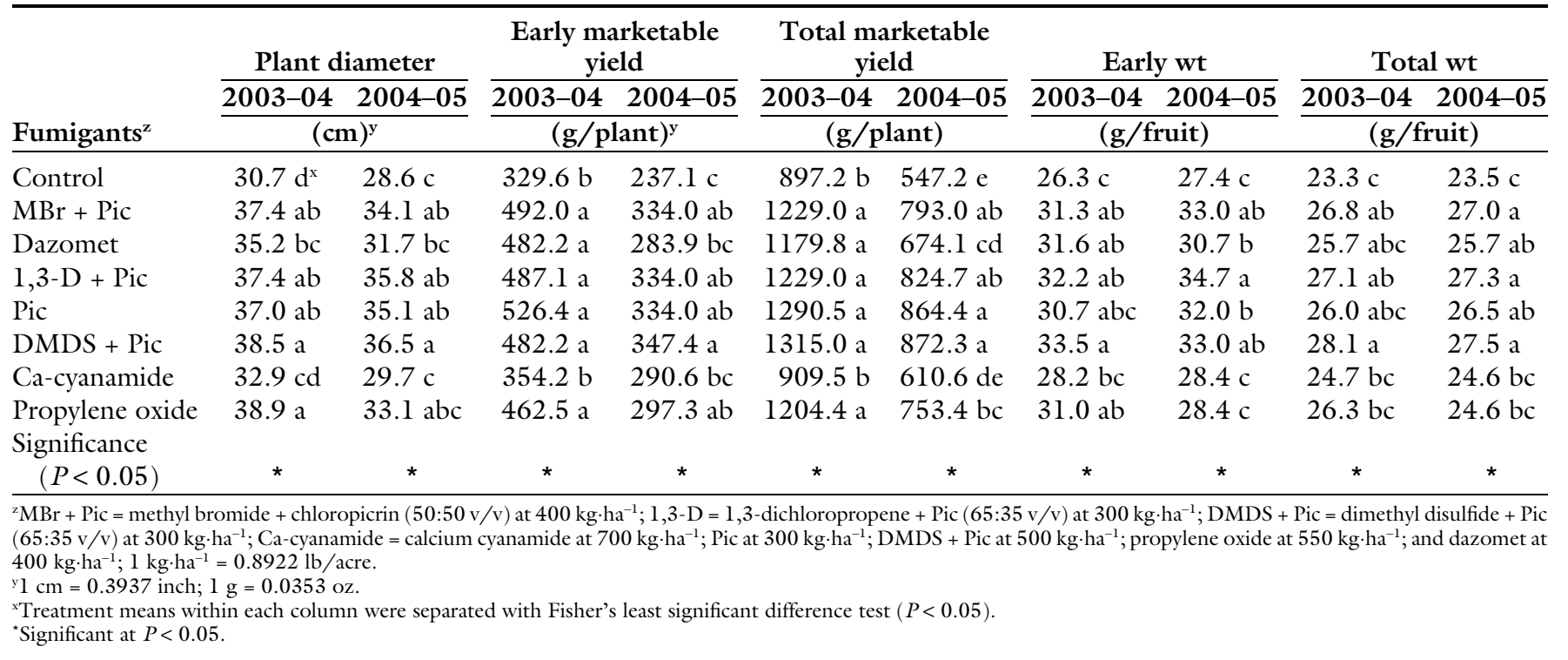

each location (Table 4). Considering across both planting seasons and locations, there were no significant total weight per fruit differences among $\mathrm{MBr}+\mathrm{Pic}$, dazomet, 1,3-D + Pic, Pic, and DMDS + Pic treatments (Tables 3 and 4).

In summary, fumigation with $\mathrm{MBr}+\mathrm{Pic}, 1,3-\mathrm{D}+\mathrm{Pic}$, Pic, and DMDS + Pic consistently improved early and total marketable strawberry yields in both locations. This response can be attributed to the successful control of soilborne fungi and nematodes species, improving strawberry growth and development, which reflected on increased plant canopy diameters and higher strawberry early and total yield. All of these fumigants could serve as part of a comprehensive soilborne disease and nematode control program for mulched-strawberry production. Dazomet might have application as a soil-applied fumigant because of its performance during both seasons and locations. However, its nematicidal activity was weak during one of the strawberry seasons. Ca-cyanamide proved to be a weak nematicide under the conditions of these trials.

\section{Literature cited}

Ajwa, H.A., S. Klose, S.D. Nelson, A. Minuto, M.L. Gullino, F. Lamberti, and J.M. López-Aranda. 2003. Alternatives to methyl bromide in strawberry production in the United States of America and the Mediterranean region. Phytopathol. Mediterr. 42:220-244.
Albritton, D.L., P.J. Aucamp, G. Megie, and R.T. Watson (eds.). 1998. Scientific assessment of ozone depletion. Global ozone research and monitoring project. Rpt. no. 44, 1998. World Meteorology Org., Geneva, Switzerland.

Belcher, J.L., R.H. Walker, and R. Rodriguez-Kabana. 2004. Acrolein and propylene oxide: Alternatives to methyl bromide for weed control in turf. Proc. Annu. Intl. Res. Conf. Methyl Bromide Alternatives and Emissions Reductions. 29 Oct. 2007. <http:// mbao.org/2004/Proceedings 04/ $023 \% 20$ BelcherJ\%20MBAO\%20abstract pdf>.

Bourdos, V.A., M.T. Skoudridakis, G.A Darakis, and M. Koulizakis. 1997. Calcium cyanamide and soil solarization for the control of Fusarium solani f.sp. cucurbitae in greenhouse cucumber. Crop Prot. 16:383-386.

Calatrava, J. 2002. Southwestern Spain strawberry growers awareness of the methyl bromide phase out and their willingness to pay for alternatives. Proc. Intl. Conf. Alternatives to Methyl Bromide. p. 321-325.

De Cal, A., A. Martinez-Treceño, J.M. Lopez-Aranda, and P. Melgarejo. 2004. Chemical alternatives to methyl bromide in Spanish strawberry nurseries. Plant Dis. $88: 210-214$.

De Los Santos, B., C. Barrau, C. Blanco, F. Arroyo, M. Porras, J.J. Medina, and F. Romero. 2003. Relationship between Trichoderma soil populations and strawberry fruit production in previously fumigated soils. HortScience 38:14001402 .
Duniway, J.M. 2002. Status of chemical alternatives to methyl bromide for preplant fumigation of soil. Phytopathology 92:1337-1343.

Elad, Y., I. Chet, and Y. Henis. 1981. A selective medium for improving quantitative isolation of Trichoderma spp. from soil. Phytoparasitica 9:5967.

Food and Agriculture Organization of the United Nations. FAOSTAT. 10 Sept. 2008. <http://faostat.fao.org/site/ $567 /$ default.aspx\#ancor>.

Gerik, J.S. 2005. Evaluation of soil fumigants applied by drip irrigation for liatris production. Plant Dis. 89:883-887.

Jeffers, S.N. and S.B. Martin. 1986. Comparison of two media selective for Phytophthora and Pythium species. Plant Dis. 70:1038-1043.

Jones, D. and E.G. Gray. 1973. Factors affecting germination of sclerotia of Sclerotinia sclerotium from peas. Trans. Br. Mycol. Soc. 60:495-500.

Ko, W.H. and F.K. Hora. 1971. A selective medium for the quantitative determination of Rhizoctonia solani in soil. Phytopathology 61:707.

Lo, C.T. and Y.S. Lin. 1989. Mechanisms of calcium cyanamide on controlling fusarium wilt of garden peas. J. Agr. Res. China 38:365-373.

López-Aranda, J.M., J.J. Medina, J.I. Marsal, and R. Bartual. 2002. Strawberry production in Spain, p. 230-237. In: N.F. Childers (ed.). The strawberry: A book for growers, others. IFAS Publ., Univ. Florida, Gainesville. 


\section{Research Reports}

Milinko, I., G. Fischl, and S. Kadlieskos. 1989. Data on epidemiology of Sclerotinia sclerotium (Lib.) de Bary. Novenytermeles 38:427-434.

Noling, J.W. and J.P. Gilreath. 2001. Methyl bromide, progress and problems: Identifying alternatives to methyl bromide, vol. II. Citrus Veg. Mag., IFAS Publ., Univ. Florida, Gainesville.

Nombela, G. and A. Bello. 1983. Modificaciones al método de extracción de nemátodos fitoparásitos por centrifugación en azúcar. Plagas 9:183-189.

Norton, J.A. 2004. IR-4 methyl bromide alternative (MBA) programs review. Proc. Annu. Intl. Res. Conf. Methyl Bromide Alternatives Emissions Reductions. 29
Oct. 2007. <http://mbao.org/2004/ Proceedings04/025\%20NortonJ\%20IR$4 \% 202004 \% 20 \mathrm{MBA} \% 20$ Presentation.pdf>.

Santos, B.M. and J.P. Gilreath. 2005 Tomato nutrient absorption and nutsedge and sting nematode management with propylene oxide. Proc. Florida State Hort. Soc. 118:166-168.

Santos, B.M. and J.P. Gilreath. 2006 Chemical alternatives to methyl bromide for vegetable crop production in Florida, United States. Perspectives Agr. Veterinary Sci. Nutr. Natural Resources 1:1-7.

Santos, B.M., J.P. Gilreath, J.M. LópezAranda, L. Miranda, C. Soria, J.J. Medina, and A. Whidden. 2006. Performance of methyl bromide alternatives for strawberry production in Florida and Spain. Proc. Florida State Hort. Soc. 119:267268.

Rosskopf, E.N., D.O. Chellemi, N. KokalisBurelle, and G.T. Church. 2005. Alternatives to methyl bromide: A Florida perspective. Plant Dis. Prog. 10-1094/PHP-20051027-01-RV.

U.S. Environmental Protection Agency. 1999. Protection of stratospheric ozone: Incorporation of Montreal protocol adjustment for a 1999 interim reduction in Class I, Group VI controlled substances. Fed. Regist. 64:29240-29245. 